\title{
Early Neoproterozoic limestones from the Gwna Group, Anglesey
}

\author{
JANA M. HORÁK* \& JANE A. EVANS $\dagger$ \\ *Department of Geology, National Museum of Wales, Cardiff CF10 3NP, Wales, UK \\ $\nmid$ NERC Isotope Geosciences Laboratory, Kingsley Dunham Centre, Keyworth, Nottingham NG12 5GG, UK
}

(Received 4 March 2009; revised version received 25 March 2010; accepted 26 March 2010; first published online 16 June 2010)

\begin{abstract}
Limestone megaclasts up to hundreds of metres in size are present within the Gwna Group mélange, North Wales, UK. The mélange has been interpreted as part of a Peri-Gondwanan fore-arc accretionary complex although the age of deposition remains contentious, proposals ranging from Neoproterozoic to Early Ordovician. This paper uses strontium isotope chemostratigraphy to establish the age of the limestone blocks and thus provide a maximum age constraint on mélange formation. Results show that, although the carbonates are locally dolomitized, primary ${ }^{87} \mathrm{Sr} /{ }^{86} \mathrm{Sr}$ ratios can be identified and indicate deposition sometime between the late Tonian and earliest Cryogenian. This age is older than that suggested by stromatolites within the limestone and indicates that the limestone did not form as cap carbonate deposits.
\end{abstract}

Keywords: Neoproterozoic, limestone, Anglesey, chemostratigraphy, mélange.

\section{Introduction}

The Gwna Group is a spectacular, regional scale mélange, estimated to be up to $3000 \mathrm{~m}$ thick (Gibbons \& McCarroll, 1993), which crops out over an area of at least $200 \mathrm{~km}^{2}$ in northwest Wales. This unit was the first such chaotic deposit ever to be described in the literature and to which the term 'mélange' was first applied (Greenly, 1919), thus it may be considered the informal 'type-locality' for mélange. Although mapped by Greenly (1919) and Matley (1928), and in parts of Llŷn more recently by Gibbons \& McCarroll (1993), the age of mélange deposition remains contentious. Palaeozoic microfossil evidence for its age (e.g. Muir et al. 1979) has been contested (Peat, 1984) and appears to contradict metamorphic data (e.g. Kawai et al. 2006). Quoted ages range from Neoproterozoic (Ediacaran) (Gibbons \& Horák, 1996; Kawai et al. 2006) to early Ordovician (Barber \& Max, 1979; Collins \& Buchan, 2004). This paper forms part of a broader study of the provenance and age of clasts within the mélange, and presents radiogenic and stable isotope evidence to establish the age of limestone megaclasts, thereby providing a constraint on the depositional age of the mélange.

\section{Gwna Group mélange}

The Gwna Group mélange has traditionally been placed at the top of the Monian Supergroup succession, a thick (up to $7500 \mathrm{~m}$ ), low-grade, polydeformed, metasedimentary sequence exposed across North Wales on Anglesey and on northwest Llŷn (Shackleton, 1954, 1969; Gibbons et al. 1994) (Fig. 1). This succession has an unproven original relationship with the adjacent crystalline Neoproterozoic rocks (the

*Author for correspondence: Jana.horak@museumwales.ac.uk
Coedana and Sarn complexes on Anglesey and Llŷn, respectively) and its age of deposition and tectonosedimentary setting have invoked much debate. The Monian Supergroup has been interpreted as part of a Neoproterozoic, peri-Gondwanan, forearc accretionary complex (Gibbons \& Horák, 1996). However, the age of the mélange formation must now be reviewed in light of recent detrital zircon U-Pb SIMS data for the South Stack Group, the basal unit of the Monian Supergroup. These data indicate a maximum depositional age for the South Stack Group of late Early Cambrian to early Middle Cambrian (Collins \& Buchan, 2004) and imply that the New Harbour and Gwna groups (Fig. 1) were deposited after this, but prior to the deposition of the overlying Arenig sediments. However, these data are inconsistent with the Gwna Group being formed during Neoproterozoic subduction. This has led to a wider re-evaluation of Monian Supergroup stratigraphy, of which this study forms a part, and provokes the suggestion that it may not be one contiguous succession as originally defined by Greenly (1919) and modified by Shackleton $(1954,1969)$.

The mélange typically forms spectacular coastal outcrops on Anglesey and Llŷn (Fig. 2) but is poorly exposed inland. Clasts range in scale from boulders through to megaclasts hundreds of metres across and can be divided into at least two suites: (1) basaltic pillow lavas with a MORB chemistry (Thorpe et al. 1984), hyaloclastites, limestone breccias, red cherty mudstones, and minor jasper, all suggestive of an oceanic affinity; (2) clasts comprising sandstones, ranging from orthoquartzite to litharenites, mudstones and shallow-water limestones. Schuster (1979) also defined an additional pebbly mudstone facies. The matrix is variable in composition and although dominantly argillaceous, it may also be coarser grained and rich in fragments of disaggregated clasts. The degree of metamorphism and deformation varies between the 


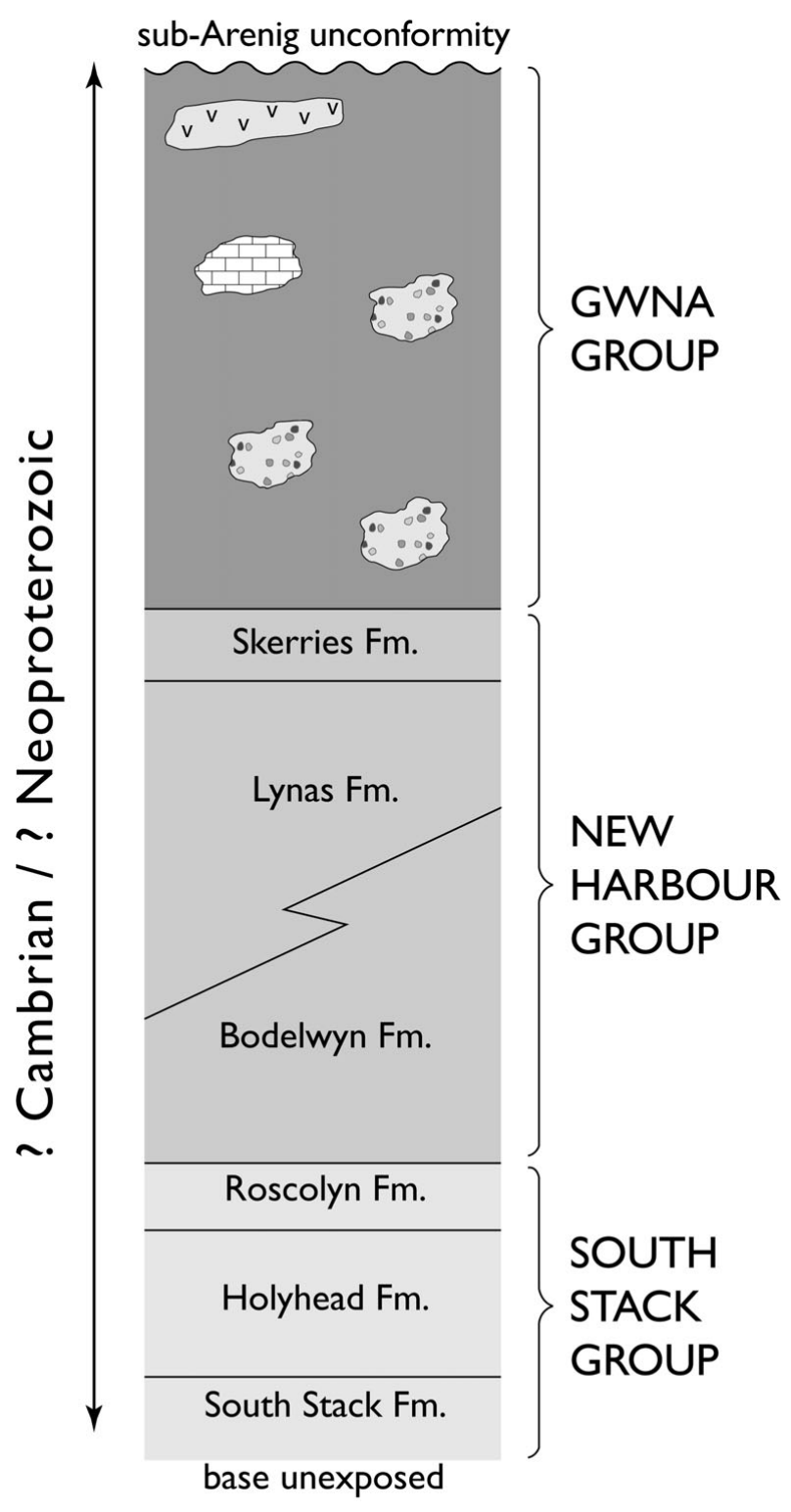

limestone $\quad \because \because \because$ sandstone $\mathrm{v}_{\mathrm{v}}^{\mathrm{v}} \mathrm{v}$ pillow lava

Figure 1. Schematic stratigraphy for the Monian Supergroup (after Shackleton, 1954, 1969; revised after M. Kohnstamm, unpub. Ph.D. thesis, Univ. Wales, Cardiff, 1983; Phillips, 1991). Large ornamented clasts within the Gwna Group are a schematic representation of megaclasts of limestone, quartzite, volcaniclastic sandstone and pillow lava. No stratigraphic relationship is implied by the relative position of the clasts.

major outcrops of the mélange. To the southwest, on Llŷn, illite crystallinity data reflect epizone conditions (Kubler Index (KI) values in the range $\Delta^{\circ} 2 \theta 0.20$ 0.26) (Merriman \& Roberts, 1985). The mélange here shows a $D_{1}$ slaty cleavage, a main $D_{2}$ folding, and minor localized $\mathrm{D}_{3}-\mathrm{D}_{5}$ deformation events (F. A. Gibbons, unpub. Ph.D. thesis, CNNA, 1980; Gibbons \& McCarroll, 1993). This contrasts with northern Anglesey, where illite crystallinity values show only diagenetic to lower anchizone grade (K.I. values in the range $\Delta^{\circ} 2 \theta 0.39-0.42$ ) (R. J. Merriman, pers. comm. 2003) and the degree of deformation appears lower.

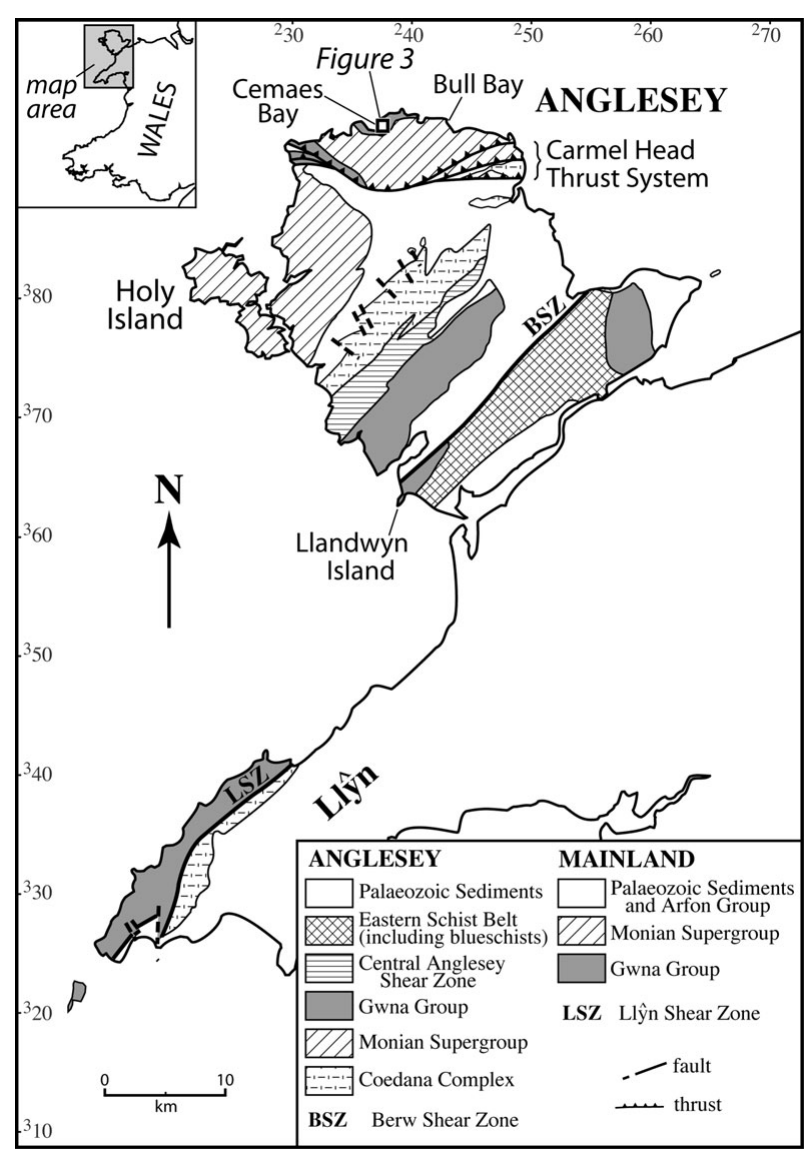

Figure 2. Simplified geological map of north Wales showing the distribution of Gwna Group and the other two components of the Monian Supergroup (South Stack and New Harbour groups).

Age constraints on the depositional age of the mélange are limited. In northern Anglesey, Arenig sediments rest unconconformably on the mélange, thereby providing a minimum age limit of around $478 \mathrm{Ma}$. On the basis of poorly preserved arcritarch assemblages extracted from cherts within the basaltic suite in the mélange at Llandwyn Island (Fig. 2), SW Anglesey, Muir et al. (1979) suggested that the mélange could be no older than Early Cambrian. However, Peat (1984) questioned these interpretations, and refuted them on the basis of the poor state of preservation of the microfossils. Stromatolites have also been described, but not figured, from a limestone megaclast in the mélange near Llanbadrig (Fig. 3) on northern Anglesey by Wood \& Nicholls (1973), who attributed unbranching stromatolites to Conophyton. Muir et al. (1979) made brief reference to more complex, branching forms that they placed in the genus Georginia. Although these authors attributed a latest Neoproterozoic to Early Cambrian age to these stromatolites, this age range is not closely constrained by the identifications given. Conophyton is a longranging genus with examples known from the early Proterozoic (2.1 Ga) to Cambrian (c. $515 \mathrm{Ma}$ ) (Grey, 1995; Walter, 1972). Further work by the authors and co-workers is therefore ongoing to establish if the taxonomy of the stromatolites can be refined. 


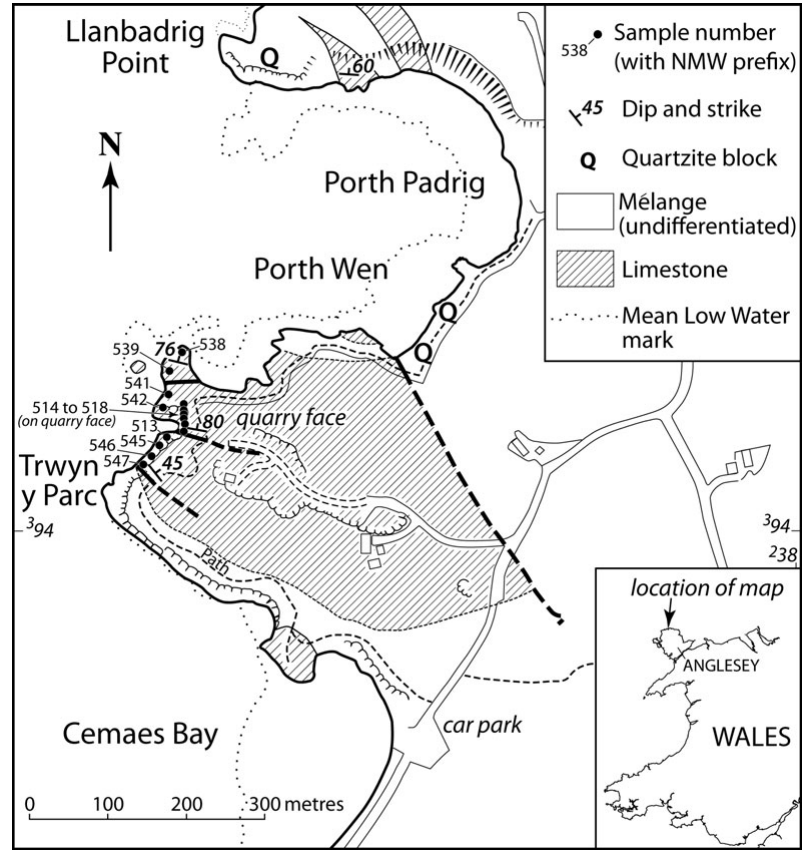

Figure 3. Location of carbonate megaclast at Trwyn y Parc, $\mathrm{N}$ Anglesey.

More recently, Kawai et al. (2006) described a prograde metamorphic sequence in SE Anglesey from metabasites of sub-greenschist facies through greenshist facies into the blueschist belt. Dallmeyer \& Gibbons (1987) dated amphibole and phengite from these blueschists as recording metamorphism at c. 550-560 Ma. This would appear to constrain the age of mélange formation to pre-550 Ma. However, M. Gyopari (unpub. M.Phil. thesis, Univ. Wales, Cardiff, 1984) also examined the greenschist-facies mélange to blueschist transition and his findings contradict those of Kawai et al. (2006), as he concluded that the boundary between the mélange and the blueschist-facies rocks was a shear zone and the two units did not form a contiguous metamorphic sequence. Clearly, characterizing the nature of the clasts and constraining the depositional age of the mélange are essential to establishing the broader tectono-sedimentary and tectono-metamorphic context in which it was formed. This paper uses a chemostratigraphic approach to re-examine the limestone megaclasts in northern Anglesey to provide additional age constraint data on the mélange.

\section{2.a. Limestone megaclasts}

A range of carbonate clasts is present within the Gwna Group mélange of Anglesey and Llŷn, showing variation in texture, composition, size and clast density. In both Llŷn and SW Anglesey, pink Mn-rich carbonate occurs interstitial to basaltic pillow lavas and as the matrix to limestone lava breccias (F. A. Gibbons, unpub. Ph.D. thesis, CNNA, 1980). Lenses of white, grey or buff limestone are dispersed throughout the mélange, and Gibbons described large, dolomitic limestone blocks from Llŷn.
The largest limestone blocks occur in northern Anglesey, where clasts from tens to hundreds of metres across have been mapped from the west side of Cemaes Bay to the west coast of Bull Bay (see Fig. 2) (Greenly, 1920). However, it is in the region immediately adjacent to Cemaes Bay that the largest limestone blocks occur where, associated typically with quartzite or grey-green sandstones, they dominate the mélange. The degree of dolomitization within the limestone varies, but appears to be lowest in the larger blocks such as that at Trywn y Parc (Fig. 3).

\section{2.b. Trwyn y Parc megaclast}

The Trwyn y Parc megaclast (Fig. 3) has a stratigraphic thickness of around $250 \mathrm{~m}$. The exposure is almost continuous along the low cliffs, and towards the middle of the section the sequence has been exposed by an agricultural lime quarry. A steep fault runs along the southern edge of the quarry; to the north of this the bedding within the carbonate dips steeply (typically $80^{\circ}$ ) to the NNE or is sub-vertical. Stromatolitic horizons indicate that the sequence youngs towards the north. South of the fault the carbonate dips more moderately at $45^{\circ}$ to the NE. The southern margin of the megaclast is brecciated and dolomitized, and shows an undulating contact with the underlying semi-pelitic mélange matrix, with tongues of matrix projecting into the limestone. The carbonate sequence can be subdivided into eight units, which reflect a progressive deepening from a sub- to peri-tidal environment.

The sequence comprises interbedded units of laminated, neomorphed micrite, microbially laminated carbonate, which may be variably dolomitized, more massive calcilutite, locally veined by calcite, and coarser calcirudite layers. The latter contains allochems that are dominated by peloidal cigar-shaped structures, up to $2 \mathrm{~mm}$ long and $0.5 \mathrm{~mm}$ wide, which are interpreted as intraclasts from reworked fragments of microbial laminated carbonate. Ooids are also present within this part of the sequence and are particularly apparent towards the northern margin of the megaclast. The entire sequence shows a variable degree of dolomitization, with the marginal units being most affected and the central portion least affected. A horizon of dolomitized pods (each up to $0.7 \mathrm{~m}$ high and $1 \mathrm{~m}$ long) is present towards the centre of the sequence and is well exposed on the north side of the quarry where it intersects the cliffs. A more detailed description and interpretation of the petrology will be presented elsewhere.

\section{Analytical techniques}

Representative samples from the lithological units described were selected for whole-rock geochemical analysis. The location of these is indicated in Figure 3. The same powders were used for whole-rock, XRD and isotopic analysis. These were first prepared by removal of all weathered surfaces; they were then 
Table 1. Geochemical analyses (ICP-MS) of carbonate samples from Trwyn y Parc

\begin{tabular}{lcrrrrrr}
\hline Sample no. & $\mathrm{SiO}_{2}(\mathrm{wt} \%)$ & $\mathrm{Sr}(\mathrm{ppm})$ & $\mathrm{Rb}(\mathrm{ppm})$ & $\mathrm{Rb} / \mathrm{Sr}$ & $\mathrm{Mn}(\mathrm{ppm})$ & $\mathrm{MgO}(\mathrm{wt} \%)$ & $\mathrm{Al}(\mathrm{ppm})$ \\
\hline NMW 538 & 0.87 & 71.2 & 0.09 & 0.000013 & 858 & 19.69 & 180 \\
NMW 539 & 0.47 & 71.2 & 0.10 & 0.000005 & 822 & 7.33 & 128 \\
NMW 541 & 0.13 & 700.9 & 0.05 & 0.000075 & 71 & 0.18 & 80 \\
NMW 542 & 1.68 & 443.9 & 0.16 & 0.000372 & 1124 & 2.16 & 58 \\
NMW 514 & 0.09 & 647.2 & 0.08 & 0.000130 & 185 & 0.22 & 283 \\
NMW 515 & 0.15 & 682.0 & 0.06 & 0.000091 & 243 & 0.18 & 19 \\
NMW 516 & 0.17 & 555.6 & 0.04 & 0.000072 & 396 & 0.69 & 35 \\
NMW 517 & 0.68 & 590.7 & 0.02 & 0.000038 & 869 & 1.58 & 103 \\
NMW 518 & 2.39 & 929.2 & 3.29 & 0.003543 & 474 & 0.44 & 2067 \\
NMW 513 & 3.30 & 1198.3 & 3.61 & 0.003010 & 299 & 0.54 & 3030 \\
NMW 545 & 2.37 & 993.1 & 4.64 & 0.004672 & 127 & 0.36 & 2648 \\
NMW 546 & 1.74 & 42.9 & 4.16 & 0.096934 & 5505 & 12.13 & 2634 \\
NMW 547 & 2.27 & 163.1 & 0.60 & 0.003697 & 1009 & 19.34 & 495 \\
\hline
\end{tabular}

Samples are arranged in sequence from the northern margin (NMW 538, top) of the megaclast to the southern margin (NMW 547, base) (see Fig. 2).

crushed, and reduced to a fine powder using an agate Tema mill. Whole-rock analysis was undertaken using a ThermoElemental ICP-MS system at Cardiff University. XRD analyses to determine the mineral content of the carbonates were made using a PANalytical X'pert PRO at the National Museum of Wales. All isotopic work was completed at the NERC Isotope Geoscience Laboratories, Keyworth.

\section{3.a. ${ }^{87} \mathrm{Sr} /{ }^{86} \mathrm{Sr}$ analysis}

Approximately 100 milligrams of powder were leached in a Teflon ${ }^{\circledR}$ beaker with dilute acetic acid in a HEPAfiltered clean air hood. The leachate was converted to chloride form and the strontium was separated using standard chromatographic exchange techniques on Dowex resin (Dickin, 1995). The samples were loaded onto single rhenium filaments using a TaF emission enhancer (Birck, 1986). The ${ }^{87} \mathrm{Sr} /{ }^{86} \mathrm{Sr}$ isotope composition of the strontium was determined using a Thermo Triton multi-collector mass spectrometer, which gave a reproducibility of $0.701222 \pm 0.000016$ $(2 \sigma, \mathrm{n}=35)$ during the analysis of these samples. All data are normalized to a value of 0.710250 for NBS 987 .

\section{3.b. $\delta^{13} \mathrm{C}$ and $\delta^{18} \mathrm{O}$ analysis}

The equivalent of $10 \mathrm{mg}$ of carbonate was reacted with anhydrous phosphoric acid in vacuo overnight at a constant $25^{\circ} \mathrm{C}$. The $\mathrm{CO}_{2}$ liberated was separated from water vapour under vacuum and collected for analysis. Measurements were made on a VG Optima mass spectrometer. Overall analytical reproducibility for these samples is normally better than $0.1 \%$ for $\delta^{13} \mathrm{C}$ and $\delta^{18} \mathrm{O}$ $(2 \sigma)$. Isotope values $\left(\delta^{13} \mathrm{C}, \delta^{18} \mathrm{O}\right)$ are reported as per mil (\%) deviations of the isotopic ratios $\left({ }^{13} \mathrm{C} /{ }^{12} \mathrm{C},{ }^{18} \mathrm{O} /{ }^{16} \mathrm{O}\right)$ calculated to the VPDB scale using a within-run laboratory standard calibrated against NBS standards.

\section{Whole-rock geochemistry}

Whole-rock geochemical data for the samples were determined to reveal extent of dolomitization and provide geochemical indicators that might reflect postdepositional modification of the primary carbonate

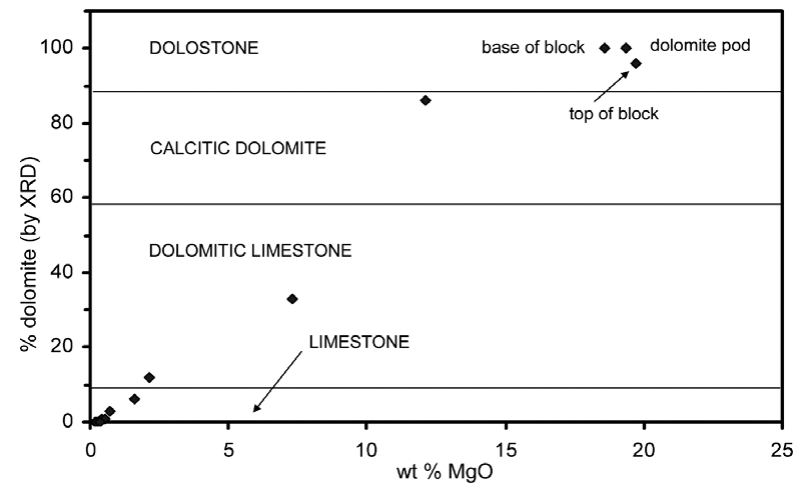

Figure 4. Classification of carbonate samples from Trwyn y Parc, N Anglesey (after Blatt, Middleton \& Murray, 1972).

isotopic signatures. Data are presented in Table 1 and plotted in Figures 4 and 5.

All samples show high carbonate content, with a maximum $\mathrm{SiO}_{2}$ content of $3.30 \mathrm{wt} \%$ and a maximum quartz content of $3 \%$ volume determined by XRD. A correlation between $\mathrm{K}_{2} \mathrm{O}$ and $\mathrm{Al}_{2} \mathrm{O}_{3}$ suggests that a few samples have a minor clay mineral content (NMW 513, 518, 545). A correlation between dolomite content and whole-rock $\mathrm{MgO}$ abundance $\left(\mathrm{R}^{2}=0.9753\right)$ indicates that all magnesium is contained within dolomite. This permits classification of the carbonates on the relative abundance of calcite and dolomite (Fig. 4).

Two samples from the top and base of the sequence (NMW 538, NMW 547), plus one from dolomite pods within the sequence (NMW 543), fall within the dolostone field containing more than $90 \%$ dolomite, one plots as a calcitic dolomite (60-90\% dolomite) (NMW 546), and two plot as dolomitic limestones (10-59\% dolomite) (NMW 539, NMW 542) (Fig. 4). All other samples are classified as limestone as they contain less than $10 \%$ dolomite. The block therefore shows clear zones of dolomitization on its margins, as indicated by the high $\mathrm{MgO}$ content.

These zones of dolomitization also show an elevated $\mathrm{Mn}$ content and higher $\mathrm{Mn} / \mathrm{Sr}$ ratios than the nondolomitized samples from the centre of the megaclast (Table 1, Fig. 5). This is a product of both an increased content of Mn and a reduction of Sr in these dolomitized 

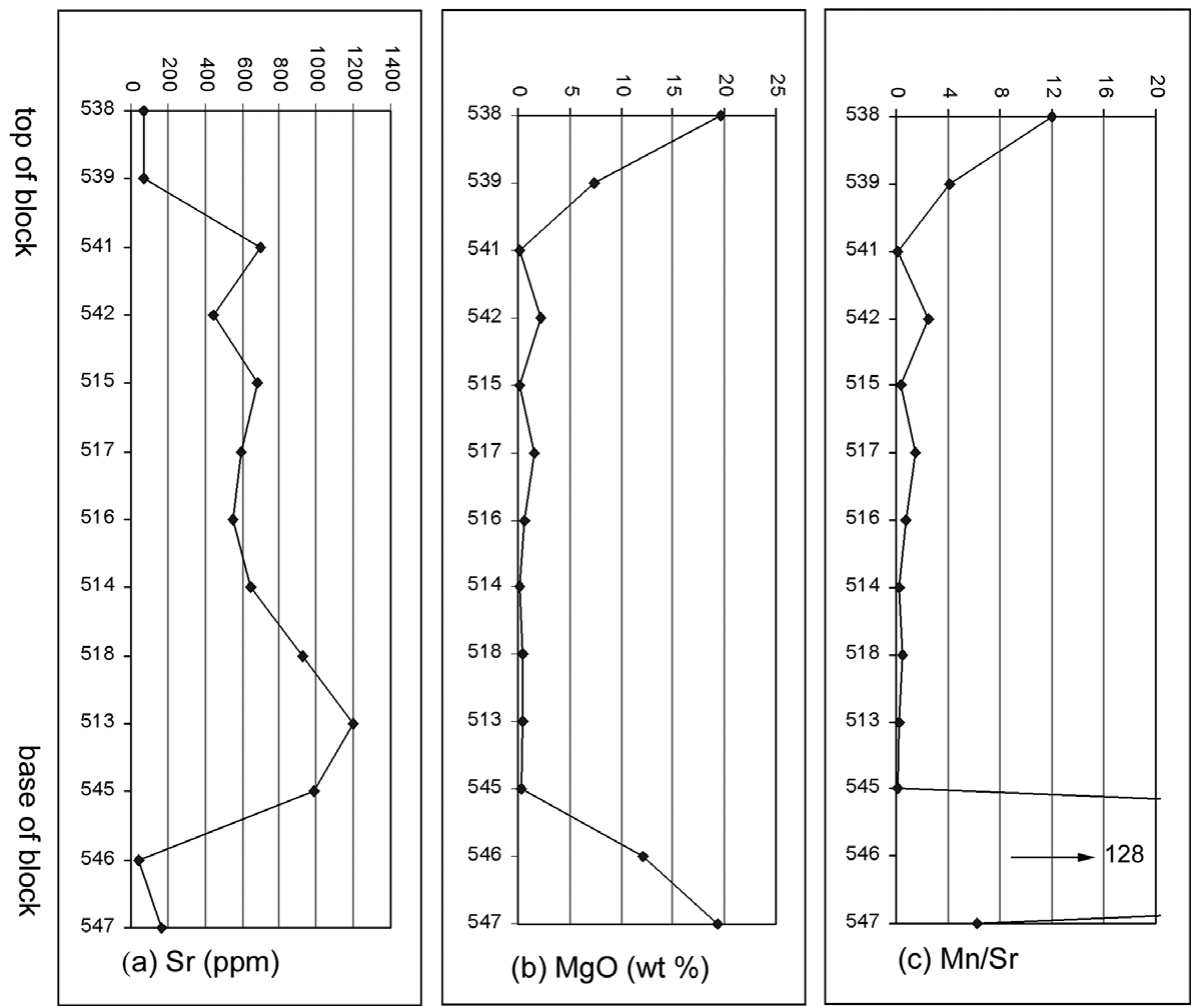

Figure 5. Geochemical data for samples from the Trwyn y Parc megaclast (see Fig. 3 for location of samples).

samples. Several workers have suggested that $\mathrm{Mn} / \mathrm{Sr}$ is a valuable indicator of post-depositional modification of isotopic signatures, most notably ${ }^{87} \mathrm{Sr} /{ }^{86} \mathrm{Sr}$, and to a lesser extent $\delta^{13} \mathrm{C}$, although the specific value used to filter modified from non-modified samples varies between studies, with little consensus (e.g. Derry et al. 1989; Asmerom et al. 1991; Kaufman, Jacobsen \& Knoll, 1993; Denison et al. 1994; McArthur, 1994; Jacobsen \& Kaufman, 1999; Fairchild et al. 2000). However, the high $\mathrm{Mn} / \mathrm{Sr}$ and low $\mathrm{Sr}$ values observed at the margins of the carbonate megaclast suggest that these dolomitized samples might well not have retained their primary ${ }^{87} \mathrm{Sr} /{ }^{86} \mathrm{Sr}$ isotopic signature.

\section{Isotopic data}

Strontium isotope data are presented in Table 2 and displayed in Figure 6, and show a systematic variation across the carbonate block. The most radiogenic ${ }^{87} \mathrm{Sr} /{ }^{86} \mathrm{Sr}$ values are found on the southern and northern margins of the clast $(0.710484-0.708824$, samples NMW 547, NMW 546; 0.707146-0.708192, NMW 539, NMW 538, respectively), whereas the limestone in the central part of block (NMW 541-NMW 545; Fig. 3$)$ is typically less radiogenic ${ }^{87} \mathrm{Sr} /{ }^{86} \mathrm{Sr}(0.706902-$ $0.706198)$.

$\delta^{18} \mathrm{O}$ and $\delta^{13} \mathrm{C}$ analyses were also undertaken on all samples. The limestone samples show strongly negative $\delta^{18} \mathrm{O}$ values, ranging from -15.7 to $-18.89 \delta^{18} \mathrm{O}$ (VPDB), whereas the dolostones, and calcitic dolomite containing $86-100 \%$ dolomite, are significantly less depleted. No correlation is observed between ${ }^{87} \mathrm{Sr} /{ }^{86} \mathrm{Sr}$
Table 2. Isotopic data for samples from the Gwna Group limestone megaclast at Trwyn y Parc

\begin{tabular}{lccc}
\hline Sample no. & $\delta^{18} \mathrm{O}(\mathrm{VPDB})$ & ${ }^{87} \mathrm{Sr} /{ }^{86} \mathrm{Sr}$ & $\delta^{13} \mathrm{C}(\mathrm{PDB})$ \\
\hline NMW 538 & -9.2 & 0.708192 & 1.1 \\
NMW 539 & -15.0 & 0.707146 & 0.3 \\
NMW 541 & -16.2 & 0.706499 & 1.4 \\
NMW 542 & -17.3 & 0.706656 & 0.8 \\
NMW 514 & -18.7 & 0.706354 & 0.9 \\
NMW 515 & -18.9 & 0.706294 & 0.2 \\
NMW 516 & -18.5 & 0.706782 & 0.8 \\
NMW 517 & -18.0 & 0.706902 & 1.1 \\
NMW 518 & -17.3 & 0.706614 & 1.2 \\
NMW 513 & -16.7 & 0.706198 & 1.4 \\
NMW 545 & -15.7 & 0.706802 & 1.9 \\
NMW 546 & -4.9 & 0.710484 & 2.1 \\
NMW 547 & -8.7 & 0.708824 & -3.6 \\
\hline
\end{tabular}

Sample sequence as in Table 1 and Figure 3; NMW 538 and NMW 547 top and base of clast, respectively.

and $\delta^{18} \mathrm{O}$. Carbon isotope data show positive values from 0.2 to $1.9 \delta^{13} \mathrm{C} \%$ o (PDB) but no systematic variation with ${ }^{87} \mathrm{Sr} /{ }^{86} \mathrm{Sr}$. However, the carbon isotope data from the limestone samples from the centre of the megaclast show a negative correlation with $\delta^{18} \mathrm{O}\left(\mathrm{R}^{2}=\right.$ 0.75) (Fig. 6d).

\section{Identifying primary isotopic signatures}

Although it is suggested by some researchers that the composition of seawater may have varied though time (e.g. Wadleigh \& Veizer, 1992; Veizer et al. 1999; Lécuyer \& Allemend, 1999), Jacobsen \& Kaufman (1999) present $\delta^{18} \mathrm{O}$ data for Neoproterozoic carbonates to indicate that values of less than $-5 \%$ o (PDB) are 


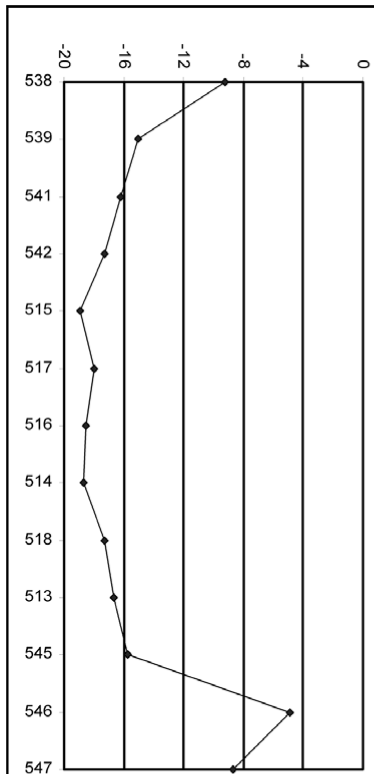

(a) $\delta^{18} \mathrm{O}(\mathrm{VDPB})$

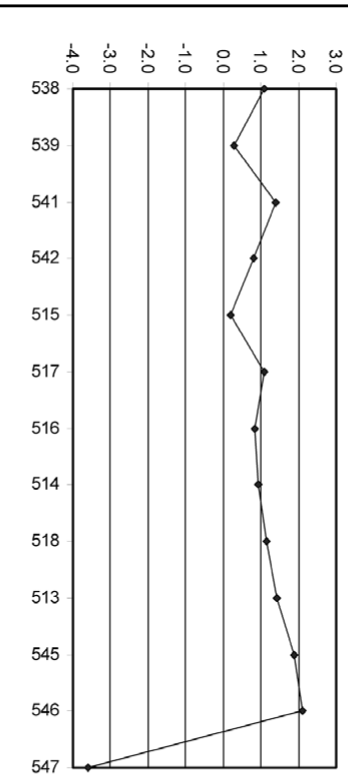

(b) $\delta^{13} \mathrm{C}$
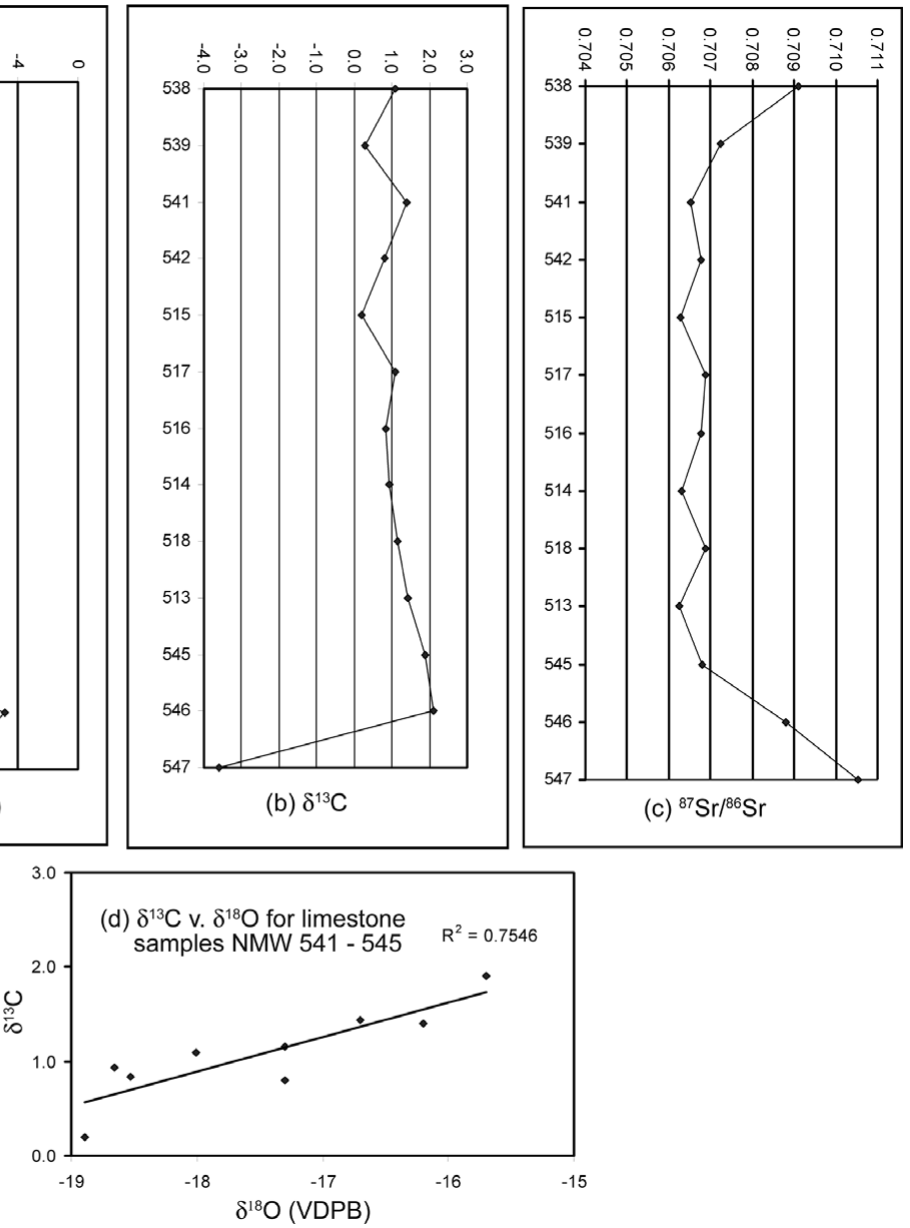

Figure 6. Isotopic data for samples from the Trwyn y Parc megaclast (see Fig. 3 for location of samples).

unlikely to represent primary isotopic signatures. Therefore the highly negative values observed in the Gwna Group carbonates are considered to have resulted from modification of the primary seawater signature during post-precipitation interaction with secondary fluids. Oxygen isotope composition is a sensitive indicator of alteration processes, with a decrease in $\delta^{18} \mathrm{O}$ values typically resulting from interaction with meteoric or hydrothermal fluids. A range of oxygen isotope values across a carbonate sequence might be anticipated as a consequence of variable oxygen mobility linked to differing degrees of recrystallization, related to the original depth of burial. Such changes are controlled by the primary carbonate texture and composition (Buick, Des Marais \& Knoll, 1995). However, the megaclast does not show a unidirectional progressive variation in $\delta^{18} \mathrm{O}$ depletion, and the marginal isotopic values show a correlation with the degree of dolomitization on the margins of the megaclasts. This distribution of values is interpreted as representing two stages of oxygen mobility. The significance of identifying these two stages of alteration is that values from one stage show a correlation with $\delta^{13} \mathrm{C}$ values, thus indicating that these values are also not primary isotopic values.

The first alteration event (resulting in values as low as about $-18.9 \delta^{18} \mathrm{O}$ ) overprinted the primary depositional $\delta^{18} \mathrm{O}$ values in the carbonate. Possible options for the derivation of the fluid involved are: (1) meteoric water, (2) hydrothermally driven fluids and (3) low-grade metamorphic fluids. The latter two options would invoke alteration of the limestone blocks after incorporation into the mélange, while textural evidence suggests that this occurred prior to incorporation. Both hydrothermal alteration, as recorded from Avalonian Neoproterozoic plutonic rocks and Acadian low-grade metamorphic fluids derived from the dehydration of mudrock within the Welsh Basin, can be reasonably ruled out, as both are enriched in heavy oxygen and have positive values (e.g. Beckinsale et al. 1984; Evans, 1995).

This early alteration event was in turn overprinted by a less pervasive event linked to dolomitization of the outer margins of the megaclast. The restricted marginal alteration indicates that this event occurred post-emplacement of the carbonate block within the mélange, with the overprinting recorded by a shift in $\delta^{18} \mathrm{O}$ from highly negative values (e.g. NMW 515 $-18.9 \%$ ) to values of $-15.7 \%$ in the limestone and -9.2 to $-8.7 \%$ in the dolostones. These samples with a second phase of oxygen mobility also show as positive correlation with $\mathrm{Mn} / \mathrm{Sr}$.

Carbon isotope systems may be less disturbed than oxygen systems during diagenetic overprint through meteoric or burial pathways, as the carbon in these 


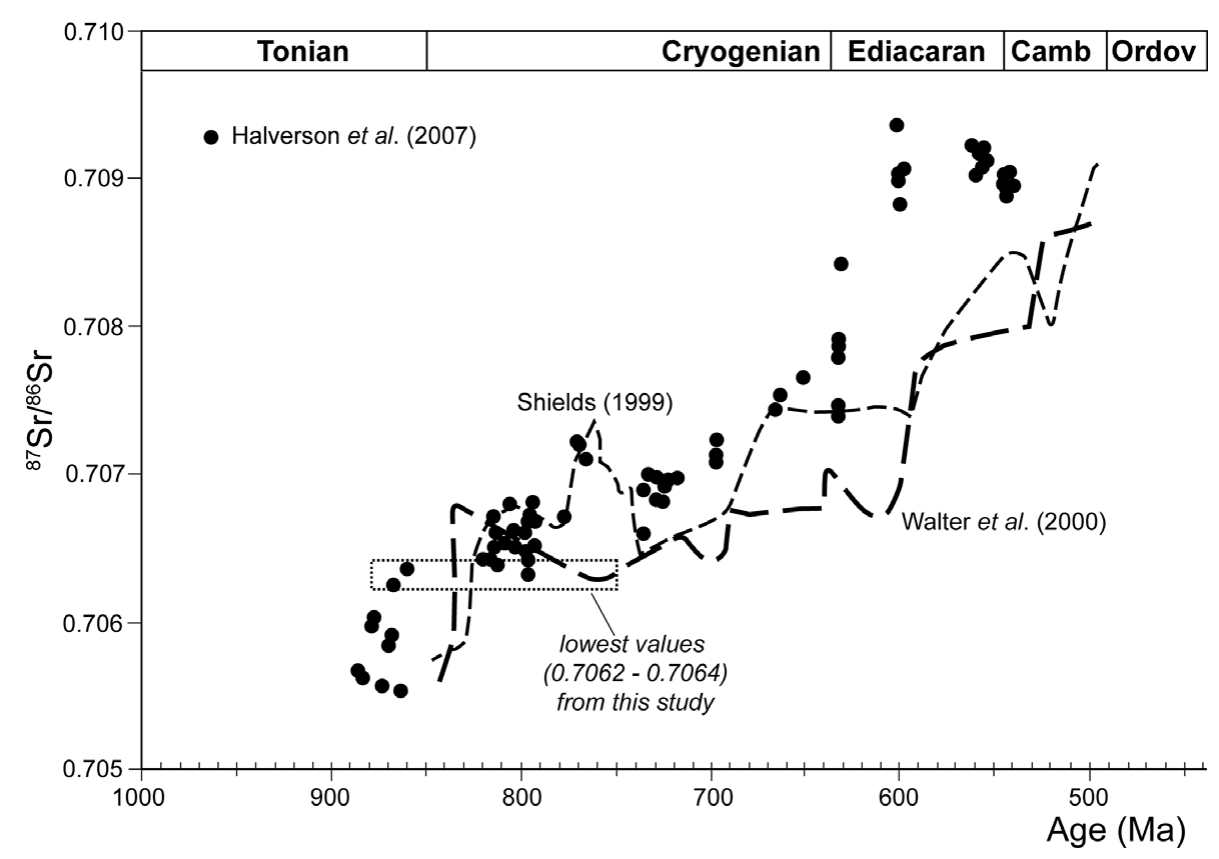

Figure 7. Age constraints on the Gwna Group limestone megaclast at Trwyn y Parc, based on seawater ${ }^{87} \mathrm{Sr} /{ }^{86} \mathrm{Sr}$ values from the Neoproterozoic to Ordovician, from the data of Halverson et al. (2007) with comparative curves from Shields (1999) and Walter et al. (2000).

fluids is derived dominantly from the precursor carbonate phases (Jacobsen \& Kaufman, 1999). However, the range of carbon isotope values shown by the nondolomitic limestone samples from the centre of the megaclast (Fig. 6; NMW 541-545, 0.2 to $1.9 \delta^{13} \mathrm{C} \%$ (PDB)) show a positive correlation between $\delta^{18} \mathrm{O}$ and $\delta^{13} \mathrm{C}$ (Fig. 6d), suggesting that the primary values have been shifted from more positive values during the first pervasive stage of alteration recorded by the highly negative $\delta^{18} \mathrm{O}$ values in these samples.

Critical to this study is the question of whether the fluid interaction caused alteration, movement or contamination of the strontium isotope composition. Because of the large reservoir of Sr in limestone (444$1198 \mathrm{ppm}$ ), it is relatively resistant to the effects of contamination by interaction with fluids. The alteration medium would need high concentrations of strontium or strontium with a very different isotopic composition (that is, highly radiogenic) in order to affect the bulk of the rock. Strontium concentration in ground water is usually less than 1 ppm (Montgomery, Evans \& Wildman, 2006). Hence, a water source of this kind, even at high water-rock ratios, is unlikely to have a significant effect on the bulk-rock isotope composition. The limited effects of interaction and isotopic exchange at the margins of the clasts, probably associated with dolomitization, are shown in Figures 5 and 6 , whereas the centre of the clast retains low $\mathrm{Sr}$ isotope values, high $\mathrm{Sr} \mathrm{ppm}$ and low magnesium contents. Consequently, the lowest $\mathrm{Sr}$ isotope values are taken as representative of the original seawater composition from which this limestone precipitated. The three lowest isotopic $\mathrm{Sr}$ values measured from the limestone are $0.70620,0.70629$ and 0.70635 . High whole-rock $\mathrm{Sr}$ and low $\mathrm{Mn} / \mathrm{Sr}(0.25-0.36)$ for these samples supports interpretation of a primary ${ }^{87} \mathrm{Sr} /{ }^{86} \mathrm{Sr}$ value in the range $0.7062-0.7064$.

\section{Secular variation in isotopic $\mathrm{Sr}$ in seawater composition}

A synthesis of published isotopic $\mathrm{Sr}$ values for carbonates of known ages has been used by various workers to document variations in the ${ }^{87} \mathrm{Sr} /{ }^{86} \mathrm{Sr}$ ratio of seawater through geological time. Data for the Neoproterozoic include the work of Asmerom et al. (1991), Kaufman, Jacobsen \& Knoll (1993), Derry et al. (1994), Nicholas (1996), Misi \& Veizer (1998), Jacobsen \& Kaufman (1999), Brasier \& Shields (2000), Montañez et al. (2000) and Melezhik et al. (2001). While these studies show a general overall trend of increasing ${ }^{87} \mathrm{Sr} /{ }^{86} \mathrm{Sr}$, with minor incursions, through the Cryogenian and Ediacaran, there are also significant differences in actual isotopic values for any given point in time between studies. This is more marked in the Cryogenian as illustrated by the curves of Walter et al. (2000) and Shields (1999) shown in Figure 7. These differences are the product of the methods and geochemical values used to identify samples considered to represent primary ${ }^{87} \mathrm{Sr} /{ }^{86} \mathrm{Sr}$ signatures, the analytical precision of isotopic analyses, and the quality of palaeontological or isotopic data used to determine the age of the carbonates. The most recent contribution by Halverson et al. (2007) presents a new seawater evolution curve for the Neoproterozoic that is based only on carbonate values that are considered to be close to original ${ }^{87} \mathrm{Sr} /{ }^{86} \mathrm{Sr}$ of seawater. This was achieved through more rigorous evaluation of existing published data, careful correlation between carbonatebearing successions on the basis of $\delta^{13} \mathrm{C}$ values, and 
identification of samples with well-constrained age data, as well as new analyses from key areas.

\section{Comparison of Gwna Limestone to seawater curves}

The lowest ${ }^{87} \mathrm{Sr} /{ }^{86} \mathrm{Sr}$ values measured from the Gwna megaclast carbonate samples lie in the range 0.7062 0.7064 . As these samples comply with the geochemical criteria identified as indicative of minimal modification of primary seawater $\mathrm{Sr}$ isotope values, they can be compared to the secular seawater curves for rocks of known age. Comparison of these samples with the data of Halverson et al. (2007) provides a minimum age of deposition of c. $800 \mathrm{Ma}$ (early Cryogenian), based on data from the Grusdiev Formation, Akademikerbreen Group, Svalbard (Fig. 7) (0.7062-0.7074), with younger ages being precluded by the continued rise in seawater ${ }^{87} \mathrm{Sr} /{ }^{86} \mathrm{Sr}$ through the Cryogenian. However, these data do not provide a unique solution, as values in the range 0.7061-0.7062 have been documented from carbonates within the Little Dal Group, Mackenzie Mountains Supergroup of NW Canada dated at 862$868 \mathrm{Ma}$ (Halverson et al. 2007). Carbonates from different sequences of early Neoproterozoic age have also been correlated on the basis of their $\delta^{13} \mathrm{C}$ signatures, and the combined use of $\delta^{13} \mathrm{C}$ and ${ }^{87} \mathrm{Sr} /{ }^{86} \mathrm{Sr}$ data would potentially provide a means of distinguishing to which of these two age groups the Gwna Group carbonates equates most closely. However, it is unfortunate both that the $\delta^{13} \mathrm{C}$ data for the two age groups overlap (Grusdiev -0.15 to 7.0 and Little Dal Group 4.0) and that the $\delta^{13} \mathrm{C}$ values for the Gwna Group carbonates have been modified during the early alteration event.

\section{Source of the megaclasts}

The Gwna Group of Anglesey lies within the Eastern Avalonian terrane of southern Britain. Within the Eastern Avalonian, or related peri-Gondwanan terranes, carbonates are poorly represented, the Neoproterozoic sedimentary sequences being dominated by arc basinal volcaniclastics and epiclastic deposits. In the type Avalonian area of Newfoundland, these deposits have been related to four main phases of magmatic arc activity spanning the period 760-545 Ma (O'Brian et al. 1992). Similar phases of activity can also be identified in southern Britain from c. 677 Ma to $560 \mathrm{Ma}$ (Gibbons \& Horák, 1996). On the basis of the $\mathrm{Sr}$ chemostratigraphy it is established that the Gwna Group megaclast limestone is older than any rocks exposed in southern Britain, and represents one of the earliest records of deposition found within the Avalonian terrane.

Within the broader peri-Gondwana-Avalonian setting, the Green Head Group of the Brookville Terrane, New Brunswick, contains rocks of late Tonian to early Cryogenian age (White \& Barr, 1996). This is interpreted as a passive margin sequence and includes carbonate rocks within the Ashburn Formation of that group. Although much of this deposit has undergone metamorphism and ductile deformation, Matthew (1890) described the columnar stromatolite Archaeozoon acadiens from less deformed parts of the sequence. More recently, Hofmann (pers. comm. cited in White \& Barr, 1996) has indicated that these suggest a Tonian to Cryogenian age for the carbonates with an age of 750-880 Ma. Although the Ashburn Formation carbonates provide a tantalizing correlative for the Gwna Group limestones, no comparable geochemical or isotopic data are available at present for this unit. However, the potential for a link between these two carbonate sequences merits a re-examination of the Gwna stromatolites.

Palaeomagnetic data for Avalonian rocks suggest a position of around $30^{\circ} \mathrm{S}$ during the late Neoproterozoic (580 to $603 \mathrm{Ma}$ ) (McNamara et al. 2001; Vizan et al. 2003), and a slightly lower latitude for the Burin Group of Newfoundland (763 Ma: Krogh et al. 1988) constrains the earliest position known for Avalonia (McCausland et al. 2008). The presence of ooids within the Gwna carbonates may indicate deposition in warmer water at low latitude, although this should not be taken as conclusive evidence without additional corroboration. James et al. (2005) have documented ooids from Neoproterozoic sequences within cold water carbonates and suggest that higher marine carbonate saturation before the evolution of skeletal carbonate biota implies that Neoproterozoic ooids may have formed across the neritic palaeoenvironmental spectrum, from polar to tropical settings. As no palaeomagnetic data are available for Avalonian rock of equivalent age to the Gwna Group limestone, the latitude of deposition remains unconstrained. The ${ }^{87} \mathrm{Sr} /{ }^{86} \mathrm{Sr}$ signature, however, does indicate that these carbonates are derived from the pre-glacial Neoproterozoic, and therefore cannot be cap carbonate deposits, as such low Sr isotope values have only ever been reported from the pre-glacial Neoproterozoic (e.g. Halverson et al. 2007).

A significant Neoproterozoic carbonate component is also present within the thick sequence of the Dalradian Supergroup of Scotland and stromatolitic carbonates have been identified within the shallowwater Bonahaven Dolomite Formation (lower Argyll Group), above the Port Askaig Tillite Formation (Fairchild, 1980). This tillite has been attributed to the Sturtian glaciation which Halverson et al. (2007) bracket with ${ }^{87} \mathrm{Sr} /{ }^{86} \mathrm{Sr}$ values of $0.7067-0.7069$. As the values for the Gwna Group limestone are considerably lower, this undermines the basis for a correlation between these limestone units. Thomas et al. (2004) have recorded a significantly lower ${ }^{87} \mathrm{Sr} /{ }^{86} \mathrm{Sr}$ value of 0.7064 from the Dufftown Limestone (Ballachulish Subgroup, Appin Group), lower in the Dalradian succession. This indicates that it was deposited around $800 \mathrm{Ma}$, and is supported by low $\delta^{13} \mathrm{C}$ values that appear to equate to the $c$. $800 \mathrm{Ma}$ Bitter Springs anomaly (Prave et al. 2009). Although the Argyll Group carbonates might provide a potential correlative 
or source for the Gwna Group mélange limestone blocks, the interbedded siliciclastic units indicate that these were deposited in a deep-water setting (Prave et al. 2009). Any association with the Dalradian succession would require the Gwna Group carbonates to be deposited close to the Laurentian margin with subsequent transfer to the Avalonian/peri-Gondwana terranes prior to the opening of Iapetus $c .600-560 \mathrm{Ma}$ (Cawood et al. 2001; Li et al. 2008).

\section{Conclusions}

(1) The Sr isotopic data presented in this paper establish an early Neoproterozoic Cryogenian (c. $800 \mathrm{Ma}$ ) or Tonian $(860 \mathrm{Ma})$ age for the limestone megaclasts within the Gwna Group mélange of Northern Anglesey, and suggest that the age range for the stromatolites reported by Wood \& Nicholls (1973) and Muir et al. (1979) is too young. Further study of the stromatolites should enable the original taxonomic work to be refined.

(2) Early Neoproterozoic rocks have not been documented from southern Britain prior to this study, the oldest rocks recorded being the Malvern Complex plutonic rocks $(677 \pm 2 \mathrm{Ma} \mathrm{U}-\mathrm{Pb}$ zircon: Tucker \& Pharaoh, 1991) and the metapelite schist from Anglesey (666 $\pm 7 \mathrm{Ma}, \mathrm{U}-\mathrm{Pb}$ zircon: Strachan et al. 2007). No evidence exists to suggest that the Gwna Group limestone was derived from a source in southern Britain. The restricted distribution of the mélange in northwestern Wales is more suggestive of a derivation from a source outboard of the main Avalonian magmatic arc.

(3) The depositional ages for the Gwna limestone megaclast derived from the $\mathrm{Sr}$ chemostratigraphy strengthen the potential correlation between the Gwna Group limestone and the Greenhead Group (Ashburn Formation) of New Brunswick. Such a correlation would also constrain the timing of mélange formation, as the Ashburn Formation underwent regional greenschist metamorphism at $560 \mathrm{Ma}$ (White \& Barr, 1996) and the Gwna limestone appears not to have exceeded anchizone conditions, which would imply incorporation into the mélange prior to this metamorphic event. In addition, if the interpretation of Kawai et al. (2006) that the Gwna Group in SE Anglesey was metamorphosed to greenschist facies during the event that produced the Anglesey blueschists at 550-560 Ma (Dallmayer \& Gibbons, 1987) is correct, then the minimum age of mélange formation must pre-date 550-560 Ma.

(4) Interpretation of a Neoproterozoic age for the Gwna Group mélange has implications for the accepted stratigraphy of the Monian Supergroup. The early Palaeozoic age for the basal part of the succession, the South Stack Group and the overlying New Harbour Group, established by Collins \& Buchan (2004), is now incompatible with the Gwna Group constituting the top unit of this succession. This suggests that the Gwna Group does not belong to the Monian Supergroup and that the stratigraphy of the group requires reexamination.

Acknowledgements. We thank Jan Zalasiewicz and Paul Smith for helpful discussion on this topic, Hilary Sloane (NIGL) for providing stable isotope data and Lin Norton for drafting figures 1,2 and 6 . We also wish to thank J. Treagus and an anonymous referee for constructive comments that improved the text. Samples used in this study are held by the National Museum of Wales under accession no. 2010.11G.

\section{References}

ASMerom, Y., Jacobsen, S. B., KnOll, A. H., ButTERFIELD, N. J. \& SweTt, K. 1991. Strontium isotope variations of Neoproterozoic seawater: implications for crustal evolution. Geochimica et Cosmochimica Acta 55, 2883-94.

BArber, A. J. \& MAX, M. D. 1979. A new look at the Mona Complex (Anglesey, North Wales). Journal of the Geological Society, London 136, 407-32.

Beckinsale, R. D., Evans, J. A., Thorpe, R. S., GibBons, W. \& HARMON, R. S. 1984. Rb-Sr whole-rock ages $\delta^{18} \mathrm{O}$ values and geochemical data for the Sarn Igneous Complex and the Parwyd gneisses of the Mona Complex of Llŷn, N. Wales. Journal of the Geological Society, London 141, 701-9.

BIRCK, J. L. 1986. Precision K-Rb-Sr Isotopic Analysis Application to $\mathrm{Rb}-\mathrm{Sr}$ Chronology. Chemical Geology 56, 73-83.

Blatt, H., Middleton, G. \& Murray, R. 1972. Origin of Sedimentary Rocks. Englewood Cliffs, New Jersey: Prentice-Hall, Inc., 634 pp.

BRAsier, M. D. \& ShIELDS, G. 2000. Neoproterozoic chemostratigraphy and correlation of the Port Askaig glaciation, Dalradian Supergroup of Scotland. Journal of the Geological Society, London 157, 909-14.

Buick, R., Des Marais, D. J. \& KNOLl, A. H. 1995. Stable isotopic compositions of carbonates from the Mesoproterozoic Bangemall Group, northwestern Australia. Chemical Geology 123, 153-71.

Cawood, P. A., MCCAusland, P. J. A. \& DunNing, G. R. 2001. Opening Iapetus: constraints from the Laurentian margin in Newfoundland. Geological Society of America Bulletin 113, 443-53.

Collins, A. \& Buchan, C. 2004. Provenance and age constraints of the South Stack Group, Anglesey, UK: U$\mathrm{Pb}$ SIMS detrital zircon data. Journal of the Geological Society, London 161, 743-6.

Dallmeyer, R. D. \& GibBons, W. 1987. The age of blueschist metamorphism in Anglesey, North Wales: evidence from ${ }^{40} \mathrm{Ar} /{ }^{39} \mathrm{Ar}$ mineral dates of the Penmynydd schists. Journal of the Geological Society, London 144, 843-50.

Denison, R. E., Koepnick, R. B., Fletcher, A., Howell, M. W. \& CallawaY, W. S. 1994. Criteria for the retention of original seawater ${ }^{87} \mathrm{Sr} /{ }^{86} \mathrm{Sr}$ in ancient shelf limestones. Chemical Geology (Isotope Geoscience Section) 112, 131-43.

Derry, L. A., Brasier, M. D., Corfield, R. M., Yu, R. A. \& YU, Z. A. 1994. $\mathrm{Sr}$ and C isotopes in Lower Cambrian carbonates from the Siberian craton: a paleoenvironmental record during the "Cambrian explosion". Earth and Planetary Science Letters 128, 671-81.

Derry, L. A., Keto, L. S., Jacobsen, S. B., Knoll, A. H. \& SwetT, K. 1989. Sr isotopic variations in 
Upper Proterozoic carbonates from Svalbard and East Greenland. Geochimica et Cosmochimica Acta 53, 2331-9.

DICKIN, A. P. 1995. Radiogenic Isotope Geology. Cambridge University Press, 452 pp.

Evans, J. A. 1995. Mineral and isotope features related to resetting of $\mathrm{Rb}-\mathrm{Sr}$ whole-rock isotope systems during low grade metamorphism. In Low-Grade Metamorphism of Mafic Rocks (eds P. Schiffman \& H. W. Day), pp. 157-69. Geological Society of America, Special Paper no. 296.

FAIRCHILD, I. J. 1980. The structure of NE Islay. Scottish Journal of Geology 16, 189-97.

FAirchild, I. J., SPIRO, B., Herrington, P. M. \& Song, T. 2000. Controls on $\mathrm{Sr}$ and $\mathrm{C}$ isotope compositions of Neoproterozoic Sr-rich limestones of East Greenland and North China. In Carbonate Sedimentation and Diagenesis in the Evolving Precambrian World (eds J. P. Grotzinger \& N. P. James), pp. 297-313. Society for Sedimentary Geology, Special Publication no. 67.

GibBOnS, W. \& HorÁk, J. M. 1996. The evolution of the Neoproterozoic subduction system: evidence from the British Isles. In Avalonian and related peri-Gondwanan terranes of the circum-North Atlantic (eds R. D. Nance \& M. D. Thompson), pp. 269-80. Geological Society of America, Special Paper no. 304.

Gibbons, W. \& McCARroll, D. 1993. Geology of the country around Aberdaron, including Bardsey Island. Memoir of the British Geological Survey, Sheet 133 (England and Wales).

Gibbons, W., Tietzsch-Tyler, D., HorÁK, J. M. \& MurPhy, F. C. 1994. Precambrian rocks in Anglesey, southwest Llŷn and southeast Ireland. In A Revised Correlation of Precambrian Rocks in The British Isles (eds W. Gibbons \& A. L. Harris), pp. 75-84. Geological Society of London, Special Report no. 2.

GreENLY, E. 1919. The Geology of Anglesey. Memoir of the Geological Survey of Great Britain no. 78, 980 pp.

GREENLY, E. 1920. 1:50,000 (\& 1 inch to the mile) Geological Map of Anglesey. Geological Survey, G.B., Special Sheet, no. 92 \& 93 with parts of $94,105 \& 106$.

GREY, K. 1995. Neoproterozoic stromatolites from the Skates Hills Formation, Savory Basin, Western Australia, and a review of the distribution of Acaciella australica. Australian Journal of Earth Sciences 42, 123-32.

Halverson, G. P., Dudás, F. O., Maloof, A. C. \& BOWRING, S. A. 2007. Evolution of the ${ }^{87} \mathrm{Sr} /{ }^{86} \mathrm{Sr}$ composition of Neoproterozoic seawater. Palaeogeography, Palaeoclimatology, Palaeoecology 256, 103-29.

Jacobsen, S. B. \& Kaufman, A. J. 1999. The Sr, C and $\mathrm{O}$ isotopic evolution of Neoproterozoic seawater. Chemical Geology 161, 37-57.

James, N. P., Narbonne, G. M., Dalrymple, R. W. \& KYSER, T. K. 2005. Glendonites in Neoproterozoic low-latitude, interglacial sedimentary rocks, northwest Canada: Insights into the Cryogenian ocean and Precambrian cold-water carbonates. Geology 33, 9-12.

Kaufman, A. J., Jacobsen, S. B. \& Knoll, A. H. 1993. The Vendian record of $\mathrm{Sr}$ and $\mathrm{C}$ isotopic variations in seawater: implications for tectonics and paleoclimate. Earth and Planetary Science Letters 120, 409-30.

KaWAi, T., Windley, B. F., Terabayashi, M., Yamamoto, H., Maruyama, S. \& IsOzaKi, Y. 2006. Mineral isograds and metamorphic zones of the Anglesey blueschist belt, UK: implications for the metamorphic development of a Neoproterozoic subduction-accretion complex. Journal of Metamorphic Geology 24, 591602.

Krogh, T. E., Strong, D. F., O’Brien, S. J. \& PapeziK, V. $\mathrm{S}$. 1988. Precise $\mathrm{U}-\mathrm{Pb}$ dates from the Avalon terrane in Newfoundland. Canadian Journal of Earth Science 25, 442-53.

LÉCUYER, C. \& ALLEMEND, P. 1999. Modelling of the oxygen isotope evolution of seawater: implications for the climate interpretation of the $\delta^{18} \mathrm{O}$ of marine sediments. Geochimica et Cosmochimica Acta 63, 351-61.

LI, Z. X., Bogdanova, S. V., Collins, A. S., Davidson, A., De WaEle, B., ERnst, R. E., FitzsiMONS, I. C. W., FUCK, R. A., LADKOCHUB, D. P., JACOBS, J., Karlstrom, K. E., Lu, S., NATAPOV, L. M., Pease, V., Pisarevsky, S. A., Thrane, A. K. \& Vernikovsky, V. 2008. Assembly, configuration, and break-up history of Rodinia: a synthesis. Precambrian Research 160, 179210.

Matley, C. A. 1928. The Precambrain Complex and associated rocks of S.W. Lleyn (Carnarvonshire). Quarterly Journal of the Geological Society of London 84, 440504.

MATthew, G. F. 1890. Eozoon and other low organisms in Laurentian rocks at St. John (Article 1). Bulletin of the Natural History Society, New Brunswick 2, 36-41.

MCARTHUR, J. M. 1994. Recent trends in strontium isotope stratigraphy. Terra Nova 6, 331-58.

McCausland, P. J. A., Murphy, J. B., Hamilton, M. A., Pisarevsky, S. \& O’Brien, S. J. 2008. Avalonia's foundation? Preliminary paleomagnetism and U$\mathrm{Pb}$ zircon geochronology of the mid-neoproterozoic Burin Group, Newfoundland. Northeast GSA Meeting, Buffalo, NY, GSA Abstracts with Programs 40, 2.

McNamara, A. K., MaC Niocaill, C., VAN DER PluiJM, B. A. \& VAN DER VOO, R. 2001. West African proximity of Avalon in the Latest Precambrian. Geological Society of America Bulletin 113, 1161-70.

MelezhiK, V. A., Gorokhov, I. M., Kuznetsov, A. B. \& FALLICK, A. E. 2001. Chemostratigraphy of Neoproterozoic carbonates: implications for 'blind dating'. Terra Nova 13, 1-11.

Merriman, R. J. \& Roberts, B. 1985. A survey of white mica crystallinity and polytypes in pelitic rocks of Snowdonia and Llŷn, North Wales. Mineralogical Magazine 49, 345-56.

MisI, A. \& VEIZER, J. 1998. Neoproterozoic carbonate sequences of the Una Group, Irece Basin, Brazil: chemostratigraphy, age and correlations. Precambrian Research 89, 87-100.

Montañez, I. P., Osleger, D. A., Banner, J. L., Mack, L. \& Musgrove, M. L. 2000. Evolution of the Sr and $\mathrm{C}$ isotope composition of Cambrian oceans. GSA Today 10, 1-7.

Montgomery, J., Evans, J. A. \& Wildman, G. 2006. ${ }^{87} \mathrm{Sr} /{ }^{86} \mathrm{Sr}$ isotope composition of bottled mineral waters for environmental and forensic purposes. Applied Geochemistry 21, 1626-34.

Muir, M. D., Bliss, G. M., Grant, P. R. \& Fisher, M. J. 1979. Palaeontological evidence for the age of some supposedly Precambrian rocks in Anglesey, North Wales. Journal of the Geological Society, London 136, 61-4.

NichOlas, C. J. 1996. The Sr isotopic evolution of the oceans during the 'Cambrian Explosion'. Journal of the Geological Society, London 153, 243-54.

O'Brian, S. J., O'Driscoll, C. F., TUCKer, R. D. \& DunNING, G. R. 1992. Four-fold subdivision of the Late Precambrian magmatic record of the Avalon Zone 
type area (east Newfoundland): nature and significance. Geological Association of Canada - Mineralogical Association of Canada, Program with Abstracts 17, A85.

PEAT, C. J. 1984. Precambrian microfossils from the Longmyndian of Shropshire. Proceedings of the Geologists' Association 95, 17-22.

PHILLIPS, E. R. 1991. The lithostratigraphy, sedimentology and tectonic setting of the Monian Supergroup, western Anglesey, North Wales. Journal of the Geological Society, London 148, 1079-90.

Prave, A. R., FAllick, A. E., Thomas, C. W. \& Graham, C. M. 2009. A composite C-isotope profile for the Neoproterozoic Dalradian Supergroup of Scotland and Ireland. Journal of the Geological Society, London 166, 845-57.

Schuster, D. C. 1979. The Gwna Mélange, a late Precambrian olistostrome sequence, North Wales, United Kingdom. Abstract, AAPG 63, 523.

SHACKLETON, R. M. 1954. The structure and succession of Anglesey and the Lleyn peninsula. Advancement of Science 11, 106-8.

ShaCKLETON, R. M. 1969. The Precambrian of North Wales. In The Precambrian and Lower Palaeozoic rocks of Wales (ed. A. Wood), pp. 1-22. Cardiff: The University of Wales Press.

SHIELDS, G. 1999. Working towards a new stratigraphic calibration scheme for the Neoproterozoic-Cambrian. Eclogae Geologicae Helvetiae 92, 221-33.

Strachan, R. A., Collins, A. S., Buchan, C., NAnce, R. D., Murphy, J. B. \& D'Lemos, R. B. 2007. Terrane analysis along a Neoproterozoic active margin of Gondwana: insights from U-Pb zircon geochronology. Journal of the Geological Society, London 164, 57-60.

Thomas, C. W., Graham, C. M., Ellam, R. M. \& FALLICK, A. E. $2004 .{ }^{87} \mathrm{Sr} /{ }^{86} \mathrm{Sr}$ chemostratigraphy of Neoproterozoic Dalradian limestones of Scotland. Journal of the Geological Society, London 161, 22942.

Thorpe, R. S., Beckinsale, R. D., PATchet, P. J., PIPER, J. D. A., Davies, G. R. \& Evans, J. A. 1984. Crustal growth and late Precambrian-early Palaeozoic plate tectonic evolution of England and Wales. Journal of the Geological Society, London 141, 521-36.

TUCKER, R. D. \& PHARAOH, T. C. 1991. U-Pb zircon ages for the Late Precambrian igneous rocks in southern Britain. Journal of the Geological Society, London 148, 435-45.

Veizer, J., AlA, D., AZMY, K., Bruckschen, P., BuHL, D., Bruhn, F., Carden, G., Diener, A., Ebneth, S., Godderis, Y., Jasper, T., Korte, C., PAWEllek, F. PODLAHA, O. \& STAUSS, H. 1999. ${ }^{87} \mathrm{Sr} /{ }^{86} \mathrm{Sr}, \delta^{13} \mathrm{C}$ and $\delta^{18} \mathrm{O}$ evolution of of Phanerozoic seawater. Chemical Geology 161, 59-88.

Vizan, H., CARney, J. N., Turner, P., IXer, R. A., Tomasso, M., Mullen, R. P. \& Clarke, P. 2003. Late Neoproterozoic to Early Palaeozoic palaeogeography of Avalonia: some palaeomagnetic constraints from Nuneaton, central England. Geological Magazine 140, 685-705.

WADLEIGH, M. A. \& VeIZER, J. $1992 .{ }^{18} \mathrm{O} /{ }^{16} \mathrm{O}$ and ${ }^{13} \mathrm{C} /{ }^{12} \mathrm{C}$ in Lower Palaeozoic articulate brachiopods: implications for the isotopic composition of sea water. Geochimica et Cosmoschimica Acta 56, 43143.

WALTER, M. R. 1972. Stromatolites and biostratigraphy of the Australian Precambrian and Cambrian. Special Papers in Paleontology 11, 268 pp., 34 pls.

Walter, M. R., Veevers, J. J., CAlver, C. R., Gorgan, P. \& Hill, A. C. 2000. Dating the 840-544 Ma Neoproterozoic interval by isotopes of strontium, carbon and sulfur in seawater, and some interpretative models. Precambrian Research 100, 371-433.

White, C. E. \& BARR, S. M. 1996. Geology of the Brookville terrane, southern New Brunswick, Canada. In Avalonian and related peri-Gondwanan terranes of the CircumNorth Atlantic (eds R. D. Nance \& M. D. Thompson), pp. 95-108. Geological Society of America, Special Paper no. 304 .

Wood, D. S. \& Nicholls, G. D. 1973. Precambrian stromatolitic limestones from Northern Anglesey. Nature 241, 65 . 